\title{
Sibynomorphus neuwiedi (Ihering, 1911) (Serpentes; Dipsadidae) and Potamojanuarius lamellatus (Semper, 1885) (Gastropoda; Veronicellidae): a trophic relationship revealed
}

\author{
Thiago Maia-Carneiro ${ }^{1 *}$ \\ Thiago Arnt Dorigo ${ }^{1}$ \\ Suzete Rodrigues Gomes ${ }^{2}$ \\ Sonia Barbosa dos Santos ${ }^{3}$ \\ Carlos Frederico D. Rocha ${ }^{1}$ \\ ${ }^{1}$ Departamento de Ecologia, Universidade do Estado do Rio de Janeiro \\ Rua São Francisco Xavier, 524, CEP 20550-019, Rio de Janeiro - RJ, Brazil \\ ${ }^{2}$ National Malacology Laboratory, United States Department of Agriculture (USDA) \\ Benjamin Franklin Parkway, 1900, Zip Code 19103, Philadelphia - PA, United States \\ ${ }^{3}$ Departamento de Zoologia, Universidade do Estado do Rio de Janeiro \\ Rua São Francisco Xavier 524, CEP 20550-019, Rio de Janeiro - RJ, Brazil \\ *Corresponding author \\ thiagomaianc@gmail.com
}

Submetido em 10/04/2011 Aceito para publicação em 14/10/2011

\section{Resumo}

Sibynomorphus neuwiedi (Ihering, 1911) (Serpentes; Dipsadidae) e Potamojanuarius lamellatus (Semper, 1885) (Gastropoda; Veronicellidae): uma relação trófica revelada. Serpentes Dispsadidae do gênero Sibynomorphus são restritas à América do Sul e englobam doze espécies atualmente reconhecidas, que ocorrem no Brasil, Argentina, Peru e Equador. Sibynomorphus neuwiedi é uma espécie endêmica de áreas florestais do bioma Mata Atlântica, sendo especializada em comer gastrópodes. Oito indivíduos adultos de $S$. neuwiedi foram coletados entre abril de 1998 e junho de 2003 no entorno de Vila dos Dois Rios (23 $11^{\prime} \mathrm{S}$,

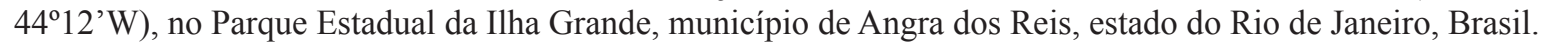
No laboratório, nós dissecamos seus estômagos para análise do conteúdo. Quatro indivíduos (50\%) continham presas em seus estômagos, todas representadas pela lesma Potamojanuarius lamellatus (Veronicellidae), e quatro indivíduos estavam com o estômago vazio. O consumo de lesmas da Família Veronicellidae por serpentes da tribo Dipsadini tem sido relatado, entretanto, a ocorrência de P. lamellatus na dieta de S. neuwiedi é aqui relatada pela primeira vez.

Palavras-chave: Gastrópodes, Lesma, Malacofagia, Predação, Serpentes

\section{Abstract}

The Dispsadidae serpents from the genus Sibynomorphus are restricted to South America and include twelve species currently known, which occur in Brazil, Argentina, Peru, and Ecuador. Sibynomorphus neuwiedi is a species endemic to forested areas of the Atlantic Rainforest biome, and it is specialized in eating gastropods. Eight 
adult individuals of S. neuwiedi were collected between April 1998 and June 2003 at the surroundings of the Vila dos Dois Rios village ( $\left.23^{\circ} 11^{\prime} \mathrm{S}, 44^{\circ} 12^{\prime} \mathrm{W}\right)$, in the Parque Estadual da Ilha Grande, in the municipality of Angra dos Reis, state of Rio de Janeiro, Brazil. In the laboratory, we dissected their stomachs for analysis of its contents. We found prey in four of them (50\%), all represented by the slug Potamojanuarius lamellatus (Veronicellidae), and four individuals had empty stomach. The consumption of slugs from the Family Veronicellidae by serpents from the tribe Dipsadini has been reported, nevertheless, we report the occurrence of $P$. lamellatus in the diet of $S$. neuwiedi for the first time.

Key words: Gastropods, Malacophagy, Predation, Serpents, Slug

The Dispsadidae serpents from the genus Sibynomorphus are restricted to South America and include twelve species currently known which occur in Brazil, Argentina, Peru, and Ecuador (CADLE, 2007). Five of these species have been reported to occur in Brazil: Sibynomorphus lavillai Scrocchi, Porto and Rey, 1993, S. mikanii (Schlegel, 1837), S. ventrimaculatus (Boulenger, 1885), S. turgidus (Cope, 1868), and S. neuwiedi (Ihering, 1911) (BÉRNILS, 2010). This last species is endemic to forested areas of the Atlantic Rainforest biome (HOGE, 1981) and, like other species of the genus, it is specialized in eating gastropods. Because of that, the species present morphological, behavioral, and physiological specializations related to its habits. These include cranial modifications and release of specific secretions of its infralabial glands that cause paralysis and death of prey (LAPORTA-FERREIRA, 1985, apud OLIVEIRA et al. 2008; LAPORTA-FERREIRA; SALOMÃO, 1991). In this communication, we report the diet of the snail-eater Sibynomorphus neuwiedi from an insular population in southeastern Brazil and report the presence of the slug Potamojanuarius lamellatus in the diet of this gastropodeating snake.

Eight adult individuals of Sibynomorphus neuwiedi (mean snout-vent length $=419.2 \pm 93 \mathrm{~mm}$, range: 216.9 $-507.3 \mathrm{~mm}$, mean tail length $=125.2 \pm 32.7 \mathrm{~mm}$, range: $61.1-155 \mathrm{~mm}$ ), were collected between April 1998 and June 2003 at the surroundings of the Vila dos Dois Rios village ( $\left.23^{\circ} 11^{\prime} \mathrm{S}, 44^{\circ} 12^{\prime} \mathrm{W}\right)$, in Parque Estadual da Ilha Grande, in the municipality of Angra dos Reis, state of Rio de Janeiro, Brazil. In the laboratory, we dissected their stomachs for analysis of its contents. We found prey in four of them $(50 \%)$, all represented by the slug P. lamellatus (mean number of prey per individual $=1.0$ \pm 1.4 , range: $0-4.0, \mathrm{~N}=8$; Veronicellidae), and four individuals had empty stomachs.
The species of slug was determined having the main references about the genus as a basis (THOMÉ, 1969; 1975 ; 1993) and also through the comparison of the holotype, kept in Zoologisches Museums der ChristianAlbrechts-Universität zu Kiel in Kiel, Germany (lot Mo-1392). Voucher specimens of the snake and of the gastropods shall be kept at Museu Nacional, in Rio de Janeiro.

The consumption of slugs from the Family Veronicellidae by serpents from the tribe Dipsadini (sensu VIDAL et al., 2010) has been reported by some authors (THOMÉ et al., 2001; MARQUES; SAZIMA, 2004; HARTMANN et al., 2009; PALMUTI et al., 2009; BERNARDE; ABE, 2010), although there was no previous record of slugs from the genus Potamojanuarius as prey of $S$. neuwiedi. The veronicellids Sarasinula marginata (Semper, 1885) and a non-identified species from the genus Novovaginula Thiele, 1831 were found in the stomach content of other Dipsadini species (THOMÉ et al., 2001), and the consumption of the gastropod Sarasinula sp. (Veronicellidae; $\mathrm{N}=4$ ) by three individuals of $S$. neuwiedi $(\mathrm{N}=5)$ was reported by Palmuti et al. (2009). The stomach content of five individuals of $S$. neuwied was analyzed and was also verified the presence of slugs from the Family Veronicellidae (MARQUES; SAZIMA, 2004).

Our data and those from literature (MARQUES; SAZIMA, 2004; PALMUTI et al., 2009) suggest that the Family Veronicellidae is often consumed by $S$. neuwiedi, being an important prey for this species of serpent. Nevertheless, the occurrence of P. lamellatus in the diet of $S$. neuwiedi is here reported for the first time. 


\section{Acknowledgements}

We thank D. Vrcibradic, who kindly revised a first draft of the manuscript and offered helpful suggestions. C.F.D. Rocha received grants from the Conselho Nacional de Desenvolvimento Científico e Tecnológico (CNPq) (Processes 304791/2010-5 and 470265/2010-8). C.F.D. Rocha also received grant from Fundação Carlos Chaga Filho de Amparo à Pesquisa do Estado do Rio de Janeiro (FAPERJ), through the program "Cientistas do Nosso Estado" (Process E-26/102.404.2009). T. MaiaCarneiro received a MsC. grant from Coordenação de Aperfeiçoamento de Pessoal de Nível Superior (Capes).

\section{References}

BERNARDE, P. S.; ABE, A. S. Food habits of snakes from Espigão do Oeste, Rondônia, Brazil. Biota Neotropica, Campinas, v. 10, n. 1, p. 167-173, 2010.

BÉRNILS, R. S. (Org.). 2010. Brazilian reptiles - List of species. Sociedade Brasileira de Herpetologia. Available at $<$ http://www. sbherpetologia.org.br/> . Accessed on: 29 March 2011.

CADLE, J. E. The snake genus Sibynomorphus (Colubridae: Dipsadinae: Dipsadini) in Peru and Ecuador, with comments on the systematics of Dipsadini. Bulletin of the Museum of Comparative Zoology, Cambridge, v. 158, n. 5, p. 183-284, 2007.

HARTMANN, P. A.; HARTMANN, M. T.; MARTINS, M. Ecology of a snake assemblage in the Atlantic Forest of southeastern Brazil. Papéis Avulsos de Zoologia, São Paulo, v. 49, n. 27, p. 343-360, 2009.

HOGE. Notes on Sibynomorphus mikanii Schlegel 1837. Memórias do Instituto Butantan, São Paulo, v. 42/43, p. 175-178, 1981.
LAPORTA-FERREIRA, I. L.; SALOMÃO, M. G. Morphology, physiology and toxicology of the oral glands of a tropical cochleophagous snake, Sibynomorphus neuwiedi (ColubridaeDipsadinae). Zoologischer Anzeiger, Berlin, v. 227, p. 198-208, 1991.

MARQUES, O. A. V.; SAZIMA, I. História Natural dos répteis da Estação Ecológica Juréia-Itatins. In: MARQUES, O. A. V.; DULEBA, W. (Ed.). Estação ecológica Juréia-Itatins: ambiente físico, flora e fauna. Holos: Ribeirão Preto, 2004. p. 257-277.

OLIVEIRA, L.; JARED, C.; PRUDENTE, A. L. C.; ZAHER H.; ANTONIAZZI, M. M. Oral glands in dipsadine "goo-eater" snakes: morphology and histochemistry of the infralabial glands in Atractus reticulatus, Dipsas indica, and Sibynomorphus mikanii. Toxicon, Glasgow, v. 51, p. 898-913, 2008.

PALMUTI, C. F. S.; CASSIMIRO, J.; BERTOLUCI, J. Food habits of snakes from the RPPN Feliciano Miguel Abdala, an Atlantic Forest fragment of southeastern Brazil. Biota Neotropica, Campinas, v. 9, n. 1, p. 263-269, 2009.

THOMÉ, J. W. Redescrição dos tipos de Veronicellidae (Mollusca, Gastropoda) Neotropicais. I. Espécies depositadas no "Zoologisches Museum"de Kiel, Alemanha. Iheringia, Porto Alegre, v. 37, p. 101-111, 1969.

THOMÉ, J. W. Os gêneros da família Veronicellidae nas Américas (Mollusca; Gastropoda). Iheringia, Porto Alegre, v. 48, p. 3-56, 1975.

THOMÉ, J. W. Estado atual da sistemática dos Veronicellidae (Mollusca; Gastropoda) americanos, com comentários sobre sua importância econômica, ambiental e na saúde. Biociências, Porto Alegre, v. 1, n.1, p. 61-75, 1993.

THOMÉ, J. W.; SANTOS, S. S.; JESKE, V. L. Novos registros de Veronicellidae (Gastropoda, Mollusca) para Itabuna, Bahia, Brasil e sua ocorrência no conteúdo estomacal de serpentes do gênero Dipsas Laurenti (Colubridae). Revista Brasileira de Zoologia, Curitiba, v. 18, n. 1, p. 301-303, 2001.

VIDAL, N.; DEWYNTER, M.; GOWER, D. J. Dissecting the major American snake radiation: A molecular phylogeny of the Dipsadidae Bonaparte (Serpentes, Caenophidia). Comptes Rendus Biologies, Paris, v. 333, n. 1, p. 48-55, 2010. 